\title{
Dairying - Waitaki's opportunity
}

Living Land Consultants Ltd, Helaman House, PO Box 86, 0 amaru

\section{Abstract}

The Waitaki Plains has 30127 ha of irrigation. The sheep, beef and cropping properties have been converted to dairy farms over recent years. Between 1989-90 and 1994-95 dairy cow numbers increased from 14000 to 39000 , mainly as a result of large operations being established. The herd size in the same time scale has increased from 292 to 443 cows per farm. Performance has also increased dramatically, with per cow production going from $260 \mathrm{~kg}$ milksolids (MS)/cow in 1986-87 to $362 \mathrm{~kg}$ MS/cow in 1995-96. The excellent stock performance is reflected in the financial gains that farmers have made. The potential for increased performance now comes from improved grass quality and growth.

Keywords: dairy conversion, dairy farming, Waitaki Plains

\section{Soil}

This subject has been well covered already in the proceedings. The one feature that must be mentioned in regard to dairy farming is the lack of pugging. This is owing to two factors:

(i) Lack of rainfall $(500 \mathrm{~mm} /$ year $)$

(ii) Most dairy soils are stony and free draining.

With little pugging it is also possible to feed supplement in the paddocks. With dairy farms averaging 443 cows on the Waitaki (Dairy statistics 1994-95), feeding supplements on the paddock saves a large quantity of capital for wintering pads and so on.

The soil type on the Waitaki Plains makes the land suited to irrigation.

\section{I rrigation}

Without irrigation there would be only a few small suppliers on the Waitaki,, these being ex town-supply properties. The low annual rainfall of $500 \mathrm{~mm}$ that makes the area ideal to live in, cannot support a large intensively run dairy unit.

The total area of irrigation on the Waitaki is 30127 ha, with 3900 ha available for irrigation in the future
(Richardson \& Hurst pers. comm.). More of this land will move into dairying unless world markets change dramatically.

\section{Pasture growth}

Figure 1 Rate of growth.

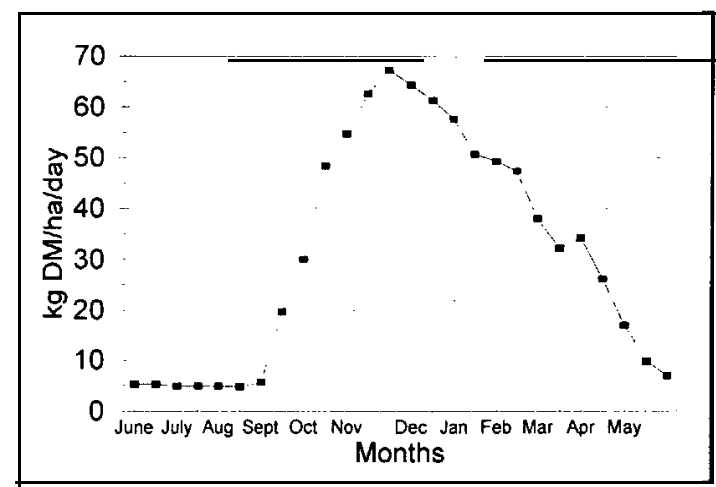

Figure 1 shows the pasture growth as presented by Greenwood \& Sheath (1981). This comes from mower cuts, using the rate-of-growth method, from 1973 to 1979. Figure 2 results are average figures from nine farms that measured pre- and post-grazing residuals with a rising plate meter from 1992 till 1995.

Figure 2 Pasture growth.

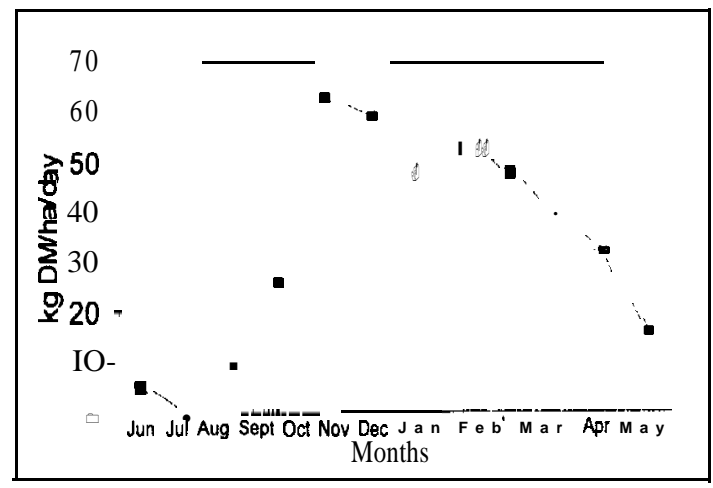

The reason for the improved spring and autumn grass growth from the farm data is the use of nitrogen. With the information collected it was not possible to separate this factor out of the information. 

are

The key features of pasture growth on the Waitaki

\section{Low annual variation in pasture production}

The pasture cutting trial showed only a $5 \%$ coefficient of variation for annual production (Greenwood \& Sheath 1981). The main reason for the low variation is the reliable irrigation system.

The consistency of pasture production is seen in the stable milk production from farms between years. This has a positive influence on cashflows which do not have the same variation as in other parts of New Zealand.

\section{Low winter gro wth}

As less than $3 \%$ of the annual grass production grows in June and July, most cows must be wintered off farm. Over the past three winters the average cost for winter grazing has been between $\$ 7$ and $\$ 11$ per cow per week, (\$56-\$110/cow/winter).

This is a considerable cost to the dairy farmer but has been useful additional income to sheep, cattle and cropping farmers in the area. With most of the 39000 cows being wintered off farm, this puts $\$ 2.2-\$ 4.3$ million into other land owners' bank accounts.

\section{Consistent growth from 10 October [ill 15March}

The consistent growth for 5 months allows dairy farmers to stock their properties fully with lactating cows. Buffers such as young stock grazing on and supplement making on the dairy farm are not common on the Waitaki.

Heifer grazing and the sale of hay and silage is now another constant source of income to other farming sectors in North Otago and South Canterbury. The significance of this payment is illustrated as follows:

\begin{tabular}{l}
\hline 200 ha irrigated sheep property (total area) \\
\hline Stock Units $\quad 3000 \mathrm{SW}$ \\
Farm Income/su $\quad \$ 48.40 /$ su $^{\prime}$ \\
Farm Income $\quad \$ 145200$ \\
\hline MAF Farm Monitoring Report 1996 \\
\hline
\end{tabular}

\begin{tabular}{lcl}
\hline $\begin{array}{l}200 \text { ha irrigated sheep property converted to a dairy unit (180 ha } \\
\text { effective) }\end{array}$ & \\
\hline cows & 495 & \\
Feed \& Grazing Expenses & $=\$ 34800$ \\
Heifer grazing & 120 hd $\times \$ 290 / \mathrm{hd}$ & $=\$ 33600$ \\
Cow Wintering & $495 \mathrm{hd} \times \$ 8.50 / \mathrm{hd} / \mathrm{wk} \times 8$ wks & $=$ \\
Supplement & $1200 \mathrm{t}$ of silage $\times \$ 40 / \mathrm{t}$ & $\$ 46000$ \\
& & $\$ 116400$ \\
\hline
\end{tabular}

In many situations by the third season after a dairy conversion, the dairy farmer is spending as much money on grazing and supplement as the sheep farm made in total income previously. The money being spent is going to agricultural contractors and other farms in the area.

The low annual variation in pasture growth has seen the Waitaki Plains grow as a dairy area over recent years. This is evident from the increased cow numbers.

\section{Cow numbers}

Figure 3 Cow numbers, Waimate and Waitaki,

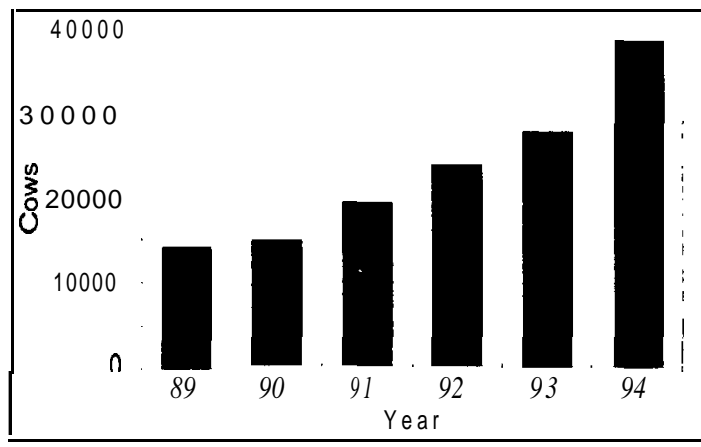

The number of cows on the Waitaki Plains has increased dramatically over the past 7 years. In 1989-90 there were just over 14000 cows in the Waimate and Waitaki district. This number had increased by 25000 to 39000 by $1994-95$. This $278 \%$ increase appears huge, but over the same period in Taranaki, cow numbers increased by 68 600. In the 1994-95 season there were more cows in Taranaki than the whole of the South Island.

The change in land use on the Waitaki Plains has been dramatic, but we do need to see ourselves nationally. The Waitaki Plains has $1.4 \%$ of the national herd. A good season in South Auckland resulting in a $4 \%$ increase in production is more than the Waitaki's total annual production.

\section{Herd size and production}

The average-sized dairy property on the Waitaki in 1994-95 was 443 cows (292 cows in 1989-90). There is only one district in New Zealand with a larger average herd size and that is Hurunui (North Canterbury). Even with the large herd size, efficiency is still being maintained. The production per hectare is higher than in Taranaki, which has an average herd size of 176 cows.

The average production per cow and per hectare has increased dramatically since 1986-87 until 1995-96. 
Figure 4 Average herd size, Waimate and Waitaki.

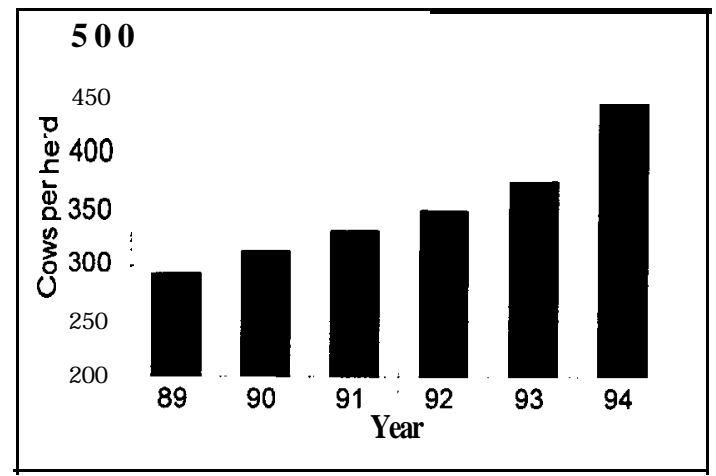

Table 1 Average figures from a group of clients.

\begin{tabular}{lcc}
\hline & $1986-87$ & $1995-96$ \\
\hline Milksolids/cow & 260 & 362 \\
Milkfat/cow & 147 & 205 \\
Milksolids/ha & 592 & 962 \\
Milkfat/ha & 334 & 544 \\
\hline
\end{tabular}

The high production levels are achieved by:

1. Long lactation

With summer dry spells eliminated by irrigation, cows can be milked from October till mid March. Lactation days are the key to high production.

2. Well-fed cows

Because supplements are available at a reasonable price, cows are well fed. Prices for feed purchased off farm are:

$\begin{array}{lrl}\text { Silage } & 15-17 & \mathrm{c} / \mathrm{kgDM} \\ \text { Grain } & 23-33 & \mathrm{c} / \mathrm{kgDM} \\ \text { (Prices are delivered on farm prices) }\end{array}$

Well-fed stock means that cows generally calve in good condition. Once the cows are lactating, feed deficits are filled with supplements. This results in a high per cow production.

The high production achieved has resulted in improved financial performance.

\section{Financial growth}

The Waitaki has been the land of opportunity. Dairy farms that were struggling to survive in 1986-1988 when payout was $\$ 2.70$ and $\$ 2.92$ (inflation adjusted) are now twice the area and making good returns. This trend is best illustrated by looking at the actual growth and development of two farms.

Table 2 Average farm area.

\begin{tabular}{lcc}
\hline & $1986-87$ & $1995-96$ \\
\hline Irrigated ha & 117 & 242 \\
Dryland ha & 23 & 81 \\
\hline
\end{tabular}

Table 3 Capital appreciation per annum'.

\begin{tabular}{lc}
\hline Farm 1 & Farm 2 \\
\hline $135 \%$ & $178 \%$ \\
\hline 1 Capital appreciation per annum is the increased net value of \\
the enterprise per annum compared to the original investment,
\end{tabular}

This compares with the New Zealand average farm size increase from 1987-88 to 1994-95 of $65-80$ ha. The average capital appreciation of land in the same time has been $20 \%$ (Dairy Statistics).

This type of growth is not seen in other traditional dairy areas where there is little land left to convert and the high value makes it impossible to expand. With the increased scale has come increased viability and improved future lifestyle for Waitaki farmers. The increased scale will allow these farmers to employ sharemilkers $(50 / 50$ or lower order) and still gain a return. This compares with areas such as Taranaki where the average farm size of 176 cows makes it impossible to retire.

So what is the Waitaki's biggest opportunity to improve profit?

\section{New grass is the key to the future}

Browntop, sweet vernal and crested dogstail with a dash of ryegrass and white clover makes up the diet of the majority of dairy cows on the Waitaki Plains. Grass species is the largest limitation to milk production.The size_of the_limitation_is_seen_from_the_following_results. (The data come from two farms run by one farmer.)

The two farms were fitted into a computer simulation model called UDDER. Their figures were then adjusted to ensure the same starting and closing cover. Cow genetics and management were the same.

The increased profit is owing to:

- more grass growth allowing a higher stocking rate

- higher quality pasture increasing milk production per cow. 
Table 4 The benefits of new grass.

\begin{tabular}{lcc}
\hline & New grass property & Old grass property \\
\hline Cows/ha & 3.1 & 2.5 \\
Production MS/ha & 1119 & 833 \\
Production MS/cow & 365 & 333 \\
Gross margin \$/ha & $\$ 2209$ & $\$ 1549$ \\
Grass eaten DM/ha & 10.4 & 8.5 \\
\hline
\end{tabular}

If new grass has obvious benefits, why isn't more land regrassed? The largest problem with new grass species is getting them established successfully. Weed grasses outcompete the new grass and the overall population of new grass decreases over time. The success of regrassing depends on the farmer and the inputs.

There are costs and problems associated with establishing new grass, but the financial benefits are huge.

\section{Summary}

The Waitaki Plains is a land of opportunity. Its soil type and low rainfall make it ideal for large scale dairy operations. This has been made possible by the irrigation of 30000 ha, which has given the area stable pasture growth.

The other key feature of pasture growth is the low winter growth. This means that most cows are wintered off farm, which is a large source of income for sheep, cattle and cropping farms.

The potential of the area has now been recognised and 39000 cows are helping change the face of the Waitaki Plains. These cows are in large herds averaging 443 cows per farm.

Production levels are excellent, $362 \mathrm{~kg}$ MS per cow being an average production level. This has helped the financial growth of the dairy farmers and therefore the community.

Improved pasture production and quality is the key to future growth. I believe plant breeders need to help farmers by ensuring new grass species establish quickly and have good longevity.

\section{REFERENCES}

Dairying Statistics 1987/88 till 1994/95. Livestock Improvement.

Richardson, G.; Hurst, S. Secretaries of the Morven, Glenavy and Lower Waitaki Irrigation Schemes.

Greenwood, P.B.; Sheath, G.W. 1981. Seasonal distribution of pasture production in New Zealand. XVI The Lower Waitaki Plains, North Otago. New Zealandjournal of experimental agriculture 9: 151155.

MAF Farm Monitoring Report, July 1996, South Region. MAF Policy, Rural Resources Unit. 